\title{
Can Tanzania Adequately Fulfill Its Public Health Regulatory Obligations Alongside Bilateral Investment Treaties Obligations?
}

\author{
Dr. Julius Cosmas ${ }^{1}$ \\ ${ }^{1}$ Lecturer in Law, Mzumbe University, Mzumbe, Tanzania \\ Correspondence: Dr. Julius Cosmas, Lecturer in Law, Mzumbe University, Po Box 9, Mzumbe, Morogoro, \\ Tanzania. E-mail: swigo2003@gmail.com
}

Received: October 23, 2014 Accepted: November 10, 2014 Online Published: May 27, 2015

doi:10.5539/jpl.v8n2p126

URL: http://dx.doi.org/10.5539/jpl.v8n2p126

\begin{abstract}
In recent years the world community has witnessed the lack of balancing between the state duty to protect the foreign investors' properties on one hand and public health on the other. Arbitral tribunals which are empowered to hear foreign investors' claims against states have, on a number of occasions, created dilemma as to whether foreign investors' obligations are superior over non-investment obligations including public health. Tribunals have failed to create a balance between these interests. This article argues that a host state has the duty to ensure that foreign investors' lives and property are protected as much as it has the obligation to ensure that public health is not compromised at the expense of attracting foreign investments. It is submitted further that these two obligations are parallel and need to be addressed simultaneously. It is concluded in this paper that the current investor - state tribunals trend of giving foreign investors' interests a priority over public health is wrong and there is a need for the tribunals to balance these two conflicting state obligations.
\end{abstract}

Keywords: international law, public health, bilateral investment treaties, international investment arbitration, international investment law

\section{Introduction}

It is a trite law that a host state has an obligation to ensure foreign investors' lives and properties are dully protected. ${ }^{1}$ The International Court of Justice (ICJ) in Barcelona Traction, Light and Power Company, Ltd (Belgium. v. Spain) ${ }^{2}$ rightly held:

'A state once it has allowed a foreigner or foreign investment in its territory whether natural or juristic persons, it becomes under duty to accord them legal protection and bears obligations with regards to treatment to be accorded to them' ${ }^{3}$

At the same time, the host state has also the duty to ensure that it fulfil other international and national legal obligations. International obligations accrue from different instruments to which the host state is a party to or from jus cogens while national obligations accrue from the respective country constitution, national laws and other regulations. ${ }^{4}$ By implementing these instruments and local legislations the state is legally discharging its sovereign duty of exercising public authority. ${ }^{5}$

\footnotetext{
${ }^{1}$ See R Dolzer \& C Schreuer Principles of International Investment Law (Oxford University Press, New York, 2008) 211; also see ZA Kronfol Protection of Foreign Investment: A study in International Law (A.W Sijthoff, Leiden, 1972) 14; see also SP Subedi International Investment Law: Reconciling Policy and Principle (Oxford University Press, London, 2008) 8; see also JW Salacuse Towards a Global Treaty on Foreign Investment: The Search for a Grand Bargain in Horn N (ed.) Arbitrating Foreign Investment Disputes: Procedural and Substantive Legal Aspects (Kluwer Law International, The Netherlands, 2004) 51-88 52 - 53; see also KJ Vandevelde 'A brief history of international investment agreements' (2005)12 University of California Davis Journal of International Law and Policy 157.

${ }^{2}$ Barcelona Traction, Light and Power Co Case (Belgium v Spain), ICJ Reports (1970).

${ }^{3}$ As above para 33 .

${ }^{4}$ I Brownlie Principles of Public International Law (Oxford University Press, London, 2008,) 292-93; also see SA Spears 'The Quest for Policy Space in a New Generation of International Investment Agreements' (2010) Journal of International Economic Law 1037 - 1075 , 1046.

${ }^{5}$ See G Van Harten, \& M Loughlin 'Investment Treaty Arbitration as a Species of Global Administrative Law' (2006) European Journal of International Law 121 at 123; see also Salacuse note 1 above, at 68-70; see also H Mann 'The Right of State to Regulate and International
} 
However, in recent years the world community has witnessed the lack of balance between the state duty to protect foreign investors' properties on one hand and public health on the other. Arbitral tribunals which are empowered to hear foreign investors' claims against states have, on a number of occasions, created a dilemma as to whether state's foreign investor obligations are superior over public health obligations. This article discusses and analyses the cases which have sparked the world community concerns. It is submitted here that protecting the health of its citizen and the foreign investors properties are both; international and national fundamental obligations. ${ }^{6}$ It is further submitted that the duty to protect public health should come as a first priority to any state as it involve its citizens' right to life.

This article is divided in five sections. The first section discusses the legal framework on the host state obligation to protect foreign investment and foreigners under international and municipal law. Tanzania legislations and international commitment to that end are discussed in this section. The second section discusses the host state general obligation to public health. The section also analyses Tanzania international commitments and national legislations on this obligation. In the third section, the article analyses briefly cases on public health vs foreign investors' rights which have sparked world attention. The fourth section discusses the parallel nature of state obligation to protect foreign investments and to regulate on public health. The fifth and last section provides the necessary recommendations and concludes the article.

\section{Obligation to Protect International Investment}

\subsection{Obligation to Protect Foreign Investments under International Law}

The state's duty to protect foreign investments is not provided in a single universal instrument but in Bilateral Investment Treaties (BITs), International Investment Agreements (IIAs) and customary rules of international law. ${ }^{7}$ BITs or IIAs are agreement made between two or more countries that safeguards investments made in the territories of the signatory countries. ${ }^{8}$ Before the proliferation of BITS and IIAs in 1990s, the protection of foreign investments was in a very fragile state. Many developing countries viewed customary law principles which demanded foreign investment to be accorded higher protection than local investments to be infringing on their sovereignty. ${ }^{9}$ However, the coming into operation of BITs and IIAs stabilised this field of law as the BITs provides foreign investors with adequate protection and at times overprotect them. ${ }^{10}$ The UNCTAD world investment Report 2014 indicates that by the end of 2013 there are 3240 BITs and IIAs scattered all over the world. $^{11}$

BITs have received a worldwide acceptance due to the fact that they come with a number of advantages to foreign investors. ${ }^{12}$ Through BITs, foreign investors are guaranteed different rights, including but not limited to; the right to compensation in case the investment is expropriated, right for the foreign investment to receive fair and equitable treatment, right for the investment to be accorded protection and security and the foreign investors' right to move capital and currency from one country to another. ${ }^{13}$ Apart from these rights, BITs also provide for procedural rights which entitle foreign investors to sue the host state without seeking prior consent from their home governments.

In summary, one may say that Investment treaties provide an extensive protection to investors' rights as a means

Investment Law: A Comment' in UNCTAD The Development Dimensions of FDI: Policy and Rule Making Perspective 2003 at 216; see also T Waelde, \& A Kolo, 'Environmental Regulation, Investment Protection and Regulatory Taking in International Law' (2004) International Comparative Law Quarterly, 811 - 848 at 811; see also B Kingsbury 'Public Law Concepts to Balance Investors' Rights with State Regulatory Actions in the Public Interest - the Concept of Proportionality' in S Schill (ed.) International Investment Law and Comparative Public Law, (Oxford University Press, London, 2010) $76-118$.

${ }^{6}$ See for example the WHO Framework Convention on Tobacco Control, (2003) 42 ILM 3, 518-539, available at http://www.fctc.org/about-fca/tobacco-control-treaty accessed on 20/06/2014. The Treaty came in force on 27/02/2005 and Tanzania ratified the Treaty 30/04/2007.

${ }^{7}$ See Salacuse, note 1 above at 54; see also SD Franck, 'The Legitimacy Crisis in Investment Treaty Arbitration: Privatizing Public International Law through Inconsistent Decisions' (2005) 73 Fordham Law Review 1521 at 1524.

${ }^{8}$ See generally United Nations Conference on Trade and Development (UNCTAD) Bilateral Investment Treaties in the Mid-1990s (1998) U N Doc UNCTAD/ITE/IIT/7, U N Sales No E 98 II D 8.

${ }^{9}$ Vandevelde, note 1 above at 157.

${ }^{10}$ A Guzman, 'Why LDCs Sign Treaties that Hurt Them: Explaining the Popularity of Bilateral Investment Treaties' (1998) 38 Vanderbilt Journal of Transnational Law, 639 at 641.

11 UNCTAD World Investment Report 2014 'investing in the SDGs: An Action Plan' at xxiii available at http://unctad.org/en/PublicationsLibrary/wir2014_en.pdf accessed on 30/06/2014.

${ }^{12}$ Franck, note 8 above at 1529 .

${ }^{13}$ Vandevelde, note 1 above at 157. 
to encourage foreign direct investment to the host state.

\subsubsection{Obligation to Protect Foreign Investment under Tanzanian BITs}

In as far as BITs are Concerned, Tanzania has concluded 17 BITs with Canada, Denmark, Egypt, Finland, Germany, Italy, Jordan, Korea, Republic of Mauritius, Netherlands, Oman, South Africa, Sweden, Switzerland, Turkey, United Kingdom and Zimbabwe. ${ }^{14}$ As pointed out in the introduction, these BITs have provisions which ensure that foreign investments are protected to the maximum level. The Tanzanian BIT provide, among other things, for the obligation to compensate in case the investment is expropriated ${ }^{15}$ obligation to treat all foreign investment fairly and equitably ${ }^{16}$ obligation to ensure that all foreign investments are accorded protection and security ${ }^{17}$ and the obligation to allow foreign investors to move capital and currency from one country to another. ${ }^{18}$

It can be concluded here that with exception of Tanzania - Canada BIT, Tanzanian BITs just like any other old generation BIT clearly guarantee foreign investment protection without placing any obligation to foreign investors.

\subsection{Obligation to Protect Foreign Investments under Tanzania Laws}

Apart from international obligations created in BITs, Tanzania as a state assumes obligations to foreign investors through national legislations. This is done by either ratifying the respective treaties or by having the constitutional provisions which provides for the protection of private property.

In as far as the constitution is concerned; Article 24 of the Constitution of United Republic of Tanzania (URT) guarantees the right to own property and the state's duty to protect such property. ${ }^{19}$ Sub article 24(2) demands for fair and adequate compensation in case of nationalisation of private property. It is submitted here that this constitutional guarantee is supposed to be interpreted in a manner that extends the protection to foreign investors.

Apart from the Constitution, the Tanzania Investment Act provides specific protection to foreign investments. ${ }^{20}$ Section 22 of the Tanzania Investment Act provides for the protection of foreign investments. ${ }^{21}$ The provision reads: 22 (a) No business shall be nationalised or expropriated by the government.

The provision further provides that in case of expropriation conducted under due process of law, payment of fair, adequate and prompt compensation shall be made. ${ }^{22}$

It can be concluded here that Tanzania has the requisite legal framework for protection of foreign investment under its national and international instruments.

${ }_{14}$ See UNCTAD Treaty Database - Bilateral Investment Treaties signed by Tanzania, available at http://unctad.org/Sections/dite_pcbb/docs/bits_tanzania.pdf accessed on 20/06/2014.

${ }^{15}$ See for example Article 4 of An Agreement between the Government of UK and Northern Ireland and the Government of the United Republic of Tanzania for the Promotion and Protection of Investment of 07/01/1994, (Hereinafter Tanzania - UK BIT) available at http://unctad.org/sections/dite/iia/docs/bits/tanzania_UK.pdf accessed on 12/05/2013; see also Art 5of An Agreement between the Government of Republic of Korea and the Government of the United Republic of Tanzania for the Promotion and Protection of Investment (hereinafter Tanzania - Korea BIT) available at http://unctad.org/sections/dite/iia/docs/bits/tanzania_Korea.pdf accessed on 12/05/2013; see also Art 6 of An Agreement between the Kingdom of Netherlands and the Government of the United Republic of Tanzania for Encouragement and Reciprocal Protection of Investments of 31/07/2001 ( hereinafter Tanzania - Netherlands BIT) available at http://unctad.org/sections/dite/iia/docs/bits/tanzania_netherlands.pdf accessed on 12/05/2013; and Art 5of the Agreement between the Government of the Republic of South Africa and the Government of the Republic of Zimbabwe for the Promotion and Reciprocal Protection of Investments of 27/11/2009 (hereinafter South Africa - Zimbabwe BIT) available at http://unctad.org/sections/dite/iia/docs/bits/south africa_zimbabwe.pdf accessed on 12/05/2013.

${ }^{16}$ As above, Art 2 of Tanzania - Korea BIT; Art 2 Tanzania - UK BIT; Art 3 Tanzania - Netherlands BIT ; Art 1 of the Treaty between the Federal Republic of Germany and the United Republic of Tanzania concerning the Encouragement and Reciprocal Protection of Investment of 30/01/1965 (hereinafter Tanzania - Germany BIT) available athttp://unctad.org/sections/dite/iia/docs/bits/tanzania_germany.pdf accessed on 12/05/2013 and Art 3 of South Africa - Zimbabwe BIT.

17 As above, Art 2 Tanzania - UK BIT.

${ }^{18}$ Art 6 of Tanzania - Korea BIT(note 20 above), Art 5 Tanzania - Netherlands BIT(note 20 above), Art 4 Tanzania - Germany BIT(note 20 above) and Art 5of the Agreement on encouragement and reciprocal protection of investments between the Republic of South Africa and the Kingdom of the Netherlands of 09/05/1995 available at http://unctad.org/sections/dite/iia/docs/bits/southafrica_netherlands.pdf accessed on 12/05/2013( hereinafter South Africa - Netherland BIT).

19 See Article 24 (1) of the United Republic of Tanzania Constitution, 1977 available at http://www.issafrica.org/cdct/mainpages/pdf/Corruption/Legislation/Tanzania/Tanzania\%20Constitution\%20in\%20English.pdf accessed on 26/04/2014.

${ }^{20}$ Tanzania Investment Act, Act No. 26 of 1997, available at $h t t p: / / w w w . t i c . c o . t z / m e d i a / I N V E S T M E N T \% 20 A C T . p d f$ accessed on 27/06/2014.

${ }^{21}$ As above, Section 22 of Tanzania Investment Act.

22 As above, section 22 (2) (a). 


\section{Obligation to Protect Public Health under International Law}

\subsection{Obligation under International Law}

The public right to health is expressly recognized in a series of international law instruments. A host state therefore is under duty to ensure that it honours the obligations created from these instruments. The main instruments which addresses the public health issue includes; the Universal Declaration of Human Rights (UDHR) ${ }^{23}$ the constitution of the World Health Organisation, ${ }^{24}$ the Convention on the Right of the Child, ${ }^{25}$ the Convention on the Elimination of All Forms of Racial Discrimination, ${ }^{26}$ the Convention on the Elimination of All Forms of Discrimination against Women, ${ }^{27}$ and the International Covenant on Economic, Social, and Cultural Rights. ${ }^{28}$ Tanzania in particular, is a member state to all these instruments by ratifying and acceding to some of them. ${ }^{29}$

Art 25(1) of the Universal Declaration of Human Rights (UDHR) clearly provides that 'everyone has the right to a standard of living adequate for the health and well-being of himself and of his family, including food, clothing, housing and medical care and necessary social services, and the right to security in the event of unemployment, sickness, disability, widowhood, old age or other lack of livelihood in circumstances beyond his control. ${ }^{30}$

On the other hand, Article 1 of the World Health Organisation declares that the World Health Organization primary objective is the attainment by all peoples of the highest possible level of health. ${ }^{31}$

In the same spirit, Article 24 (1) of the Convention on the Right of the Child demands State Parties to the convention to recognize the right of the child to enjoy highest attainable standard of health and to facilities for the treatment of illness and rehabilitation of health. ${ }^{32}$

Right to health is also guaranteed under the Convention on the Elimination of All Forms of Racial Discrimination. ${ }^{33}$ Article 5(e) (iv) clearly guarantees economic, social and cultural rights in particular with regard to the right to public health, medical care, social security and social services. The same is guaranteed under Article 11(1) (f) the Convention on the Elimination of All Forms of Discrimination against Women. ${ }^{34}$

Lastly but not least, Article 12 of the International Covenant on Economic, Social, and Cultural Rights provides that the States Parties to the Covenant recognize the right of everyone to the enjoyment of the highest attainable standard of physical and mental health. ${ }^{35}$

The UN Committee on Economic, Social and Cultural Right (ECOSOC) has interpreted the state's failure to fulfil its obligation to public health as:

... the failure of a State to take all necessary measures to safeguard persons within their jurisdiction from infringements of the right to health by third parties. This category includes such omissions as the failure to regulate the activities of individuals, groups or corporations so as to prevent them from violating the right to health of others; the failure to protect consumers and workers from practices detrimental to health, e.g. by $\ldots$ the failure to discourage production, marketing and consumption of tobacco ... the failure to

\footnotetext{
23 See the Universal Declaration of Human Right, GA res 217A (III) available at http://www.ohchr.org/EN/UDHR/Documents/UDHR_Translations/eng.pdf accessed on 24/05/2014.

24 See the WHO Constitution, 1946 available at $h t t p: / / w w w . w h o . i n t / g o v e r n a n c e / e b / w h o \_c o n s t i t u t i o n \_e n . p d f$ accessed on 25/06/2014.

${ }^{25}$ The Convention on the Right of the Child, 198928 ILM 1457, available at http://www.ohchrorg/Documents/ProfessionalInterest/crc.pdf accessed on $26 / 06 / 2014$.

26 Convention on the Elimination of All Forms of Racial Discrimination, $1965 \quad 660$ UNTS 195, available at http://www.ohchr.org/EN/ProfessionalInterest/Pages/CERD.aspx accessed on 05/06/2014.

27 Convention on the Elimination of All Forms of Discrimination Against Women, 1979 1249 UNTS 13 , available at http://www.ohchr.org/Documents/ProfessionalInterest/cedaw.pdf accessed on 23/05/2014.

${ }^{28}$ International Covenant on Economic, Social, and Cultural Rights available at http://www.who.int/hhr/Economic_social_cultural.pdf accessed on 12/06/2014.

${ }^{29}$ Tanzania ratified to the Convention on the Rights of the Child on 10/06/ 1991; acceded to the Convention on Elimination of All form of Racial Discrimination on 27/10/1971; ratified to the Convention on the Elimination of All Forms of Discrimination Against Women on 20/08/1985; ratified the International Covenant on Economic, Social and Cultural Rights on 11/06/1976.

30 See the Universal Declaration of Human Right, note23 above.

31 See the WHO Constitution, (note 24 above).

32 The Convention on the Right of the Child, note 25 above.

${ }^{33}$ Convention on the Elimination of All Forms of Racial Discrimination, note 26 above.

${ }^{34}$ Convention on the Elimination of All Forms of Discrimination against Women, note 27 above.

35 International Covenant on Economic, Social, and Cultural Rights (note 28 above)
} 
discourage the continued observance of harmful ... cultural practices. ${ }^{36}$

From the preceding it can be concluded here that indeed states have committed themselves in ensuring that public health is protected. The above named treaties and covenants have been signed by majority of world nations. Most of the above cited instruments are UN documents which mean they have been endorsed by 194 member states to the UN. ${ }^{37}$ The UN Declaration of Human right for example applies to all 194 UN member state countries. ${ }^{38}$ WHO also constitute all UN member states, which means all 194 UN Members have committed themselves to the WHO Constitutional requirement on public health. ${ }^{39}$ Tanzania joined the UN 5 days after its independence on $14^{\text {th }}$ December 1961 which means the above discussed health provisions have a place of application in the country.

For dualist countries like Tanzania, an acceded international instrument does not have a force of law until the same has been ratified and a law is passed to implement it. ${ }^{40}$ It follows therefore that the importance of ratification cannot be overemphasized. In the following section, the local legal regime is analysed to see how efficiently it is protecting public health.

\subsection{Public Health Obligation under Tanzanian BITs}

Tanzania is among states which are still embracing the BITs which are normally referred to as 'first generation BITs'. ${ }^{41}$ The so called first generation BITs were concluded before and during 1990s. They widely provides for foreign investment protection without imposing any obligations to foreign investors. ${ }^{42}$ These BITs do not acknowledge that host states have the right and the duty to regulate in pursuit of policy objectives other than investment promotion and protection. As pointed out earlier, Tanzania has concluded 17 BITs with Canada, Denmark, Egypt, Finland, Germany, Italy, Jordan, Korea, Republic of Mauritius, Netherlands, Oman, South Africa, Sweden, Switzerland, Turkey, United Kingdom and Zimbabwe. ${ }^{43}$ Out of all these 17 BITs only Tanzania - Canada BIT which was signed recently on $17^{\text {th }}$ May 2013 provides for an article addressing health and social values. ${ }^{44}$ Article 15 of the BIT provide as follows:

The Parties recognize that it is inappropriate to encourage investment by relaxing domestic health, safety or environmental measures. Accordingly, a Party should not waive or otherwise derogate from, or offer to waive or otherwise derogate from, such measures as an encouragement for the establishment, acquisition, expansion or retention in its territory of an investment of an investor. If a Party considers that the other Party has offered such an encouragement, it may request consultations with the other Party and the two Parties shall consult with a view to avoiding any such encouragement.

The rest of the treaties which were almost entered in the 1990s and early 2000s are silent on health matters. It is through such silence that tribunals finds excuses and ignore health issues in the course of interpreting BITs obligations.

\subsection{Public Health Obligation under National Legal Framework}

National legal framework plays a significant role in as far as protection of public health of the respective country is concerned. It is through a national legal framework that the international obligations of any country can be effectively implemented at national level.

As usual, the constitution, as the mother law of the country takes primacy. The United Republic of Tanzania Constitution is silent on state's obligation to protect public health. However, Article 9(i) obliges the state authorities and all its agencies to direct their policies and programmes towards ensuring the use of national

\footnotetext{
${ }^{36}$ General Comment 14, The right to the highest attainable standard of health, UN Doc. E/C.12/2000/4, 11 August 2000 available at http://www.refworld.org/publisher,CESCR, GENERAL,,4538838d0,0.html accessed on 15/06/2014.

${ }^{37}$ See the UN List of Member States available at http://www.un.org/en/members/growth.shtml accessed on 23/06/2014.

${ }^{38}$ Ibid.

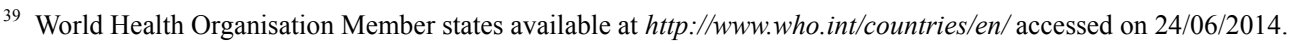

${ }^{40}$ Vereshchetin, SV, New Constitutions and the Old Problem of the Relationship between International Law and National Law, European Journal of International Law, 1996, vol. 7, at 29.

${ }^{41}$ Spears, note 5 above at 1045 .

42 As above, at 1040 .

${ }^{43}$ See UNCTAD Treaty Database, note 14 above.

${ }^{44}$ See Agreement between the Government of Canada and the Government of the United Republic of Tanzania for the Promotion and Reciprocal Protection of Investments of 17/05/2013 available at http://www.international.gc.ca/trade-agreements-accords-commerciaux/agr-acc/fipa-apie/tanzania-text-tanzanie.aspx?lang=eng accessed on $23 / 06 / 2014$
} 
resources for development of the people and particularly geared towards the eradication of poverty and disease. ${ }^{45}$ In addition, the Constitution has a provision on the right to life under Article 14 which provides that every person has the right to life and to the protection of their life to society in accordance with the law. ${ }^{46}$ Furthermore, Article 30(2) (b) calls for enactment of laws to ensure public health. ${ }^{47}$

To implement the constitutional requirement under Article 30(2) (b) the government enacted the Public Health Act, $2009 .^{48}$ The preamble to the Act clearly state the objective of the legislation as to provide for the promotion, preservation and maintenance of public health with a view to ensuring the provisions of comprehensive, functional and sustainable public health services to the general public and to provide for other related matters'. Section 3 of the defines public health as;

... a national health, community health and individual health which is primarily aimed at increasing the well-being of the population by providing essential public health services to all citizens of Mainland Tanzania. ${ }^{49}$

Section 5 (c) on the other hand obligates public authority to safeguard and promote public health standards.

Therefore, as per the Constitution and the Public Health Act it is the duty of the state to ensure that public health standard is maintained and to take all necessary measures to ensure that public health is not compromised. In doing so, the state as a sovereign has the power to enact any law or policy which might be relevant to achieve the maintenance and protection of public health.

\section{Investor - State Cases at Loggerhead with Public Health Protection}

It is always said charity begins at home. In Biwater Gauff (Tanzania) Ltd v United Republic of Tanzania ${ }^{50}$ public health was an issue which motivated the Tanzanian government to interfere with the foreign investor's rights. The facts in brief were that in 2003 a British - German joint venture - Biwater Gauff Tanzania (hereinafter "BGT") won a bid from the World Bank to renovate and upgrade and the water system in the city of Dar es Salaam Tanzania. ${ }^{51}$ The firm miscalculated when bidding for the project to the extent that 18 months down the road it found itself in deep financial difficulties and unable to supply water as required. The water supply services deteriorated threatening the outbreak of cholera and other related diseases. ${ }^{52}$ As a custodian of public health, the government of Tanzania decided to take charge of the management and the supply of water in the city. ${ }^{53}$ Henceforth on 13 May 2005, the Minister of Water and Livestock Development issued a press release terminating the contract project with the claimant. ${ }^{54}$ BGT was aggrieved by the government move and decided to institute a claim at ICSID pursuant to Tanzania - UK BIT ${ }^{55}$ alleging breach on expropriation, fair and equitable treatment, full protection and security, discrimination and unrestricted transfer of capital guarantees. ${ }^{56}$

The Tribunal found Tanzania in breach of the UK - Tanzania BIT but fortunately awarded no damages to the claimant on the ground that the breaches of the BIT did not cause City Water any losses and that the Claimant's cannot benefit from its own failures in the performance of the project contract. ${ }^{57}$

It is should be borne in mind here that the government exercised the powers to prevent the possible outbreak of cholera as provided under section 4(1) (c) of the Public Health Act and The International Health Regulations, 2005 as adopted by the World Health Assembly to which Tanzania is a party. ${ }^{58}$

Another investor - state case on health issues is Philip Morris Asia Ltd v The Commonwealth of Australia. ${ }^{59}$ In

${ }^{45}$ The United Republic of Tanzania Constitution Article 9(i), note 19 above.

${ }^{46}$ As above, Article 14.

${ }^{47}$ As above, Article 30 (2) (b).

48 The Public Health Act, Act No. 16 of 2009.

49 As above, Section 3 - a definition section.

50 Biwater Gauff (Tanzania) Ltd $v$ United Republic of Tanzania, Final Award of $24^{\text {th }}$ July 2008 available at http://icsid.worldbank.org/ICSID/FrontServlet?requestType $=$ CasesRH\&actionVal=showDoc\&docId=DC770_En\&caseId =C67

${ }^{51}$ Biwater above para 3.

52 Biwater above para 789.

${ }^{53}$ Biwater above para 436.

${ }^{54}$ Biwater above para 792.

${ }^{55}$ Tanzania - UK BIT (note 19 above).

${ }^{56}$ Biwater note 50 above para 205.

${ }^{57}$ Biwater above para 519; see also para 773 - 808 .

${ }^{58}$ See the World Health Regulations, 2005 available at $h t$ tp://www.who.int/ihr/publications/9789241596664/en/accessed on 23/05/2014.

59 Philip Morris Asia Ltd $v$ The Commonwealth of Australia UNCITRAL, PCA Case No. 2012 - 12 available at 
June 2011, Philip Morris Asia Limited (based in Hong Kong), a manufacturer, importer and distributor of cigarettes commenced the investment treaty claim against Australia alleging that Australia's plain cigarette packaging legislation, (the Plain Packaging Act, 2011) contravenes Australia's - Hong Kong bilateral investment treaty (BIT) ${ }^{60}$

The Tobacco Plain Packaging Act 2011 bans the use of cigarette companies' logos on cigarette packets and replaces them with health warnings. ${ }^{61}$ The name of the cigarette companies are required to appear in the same font and size as other words on the cigarette packets.

The Claimant, Philip Morris Asia Limited, argues that the law is depriving it of the value of its investment in trademarks and other intellectual property in Australia and this is tantamount to expropriation. ${ }^{62}$ The claim is essentially based on expropriation of intellectual property without compensation under Article 6 of the Australia-Hong Kong BIT and a breach of fair and equitable treatment under Article 2(2) of the Australia-Hong Kong BIT. ${ }^{63}$ The claimant is therefore asking the Tribunal to order Australia to suspend enforcement of Plain Packaging Act and to compensate the Claimant for loss suffered through compliance. Alternatively, the claimant asks the Tribunal to order Australia to compensate the Claimant for loss suffered as a result of the enactment and continued application of plain packaging legislation. ${ }^{64}$

The case is still pending and is to be adjudicated in accordance to UNCITRAL rules $2010 .^{65}$

As it can be gathered from the claimant pleadings, the Tribunal is asked to suspend the application of the law which is passed by the Australian parliament in accordance to the state regulatory powers. The legislation aims at protecting public health, and is in line with the World Health Organisation Framework Convention on Tobacco Control. ${ }^{66}$ Therefore Australia is not only protecting its citizens' health but fulfilling its WHO international obligation.

Another case is Vattenfall AB and others v. Federal Republic of Germany. ${ }^{67}$ In May 2012 the Swedish energy company Vattenfall filed a request for arbitration at ICSID against the Republic of Germany and the Tribunal was dully constituted on $14^{\text {th }}$ December $2013 .^{68}$ The case resulted from the Germany decision to opt out of nuclear energy by 2022 following the Fukushima disaster in March 2011. ${ }^{69}$ The Federal Atomic Energy Act was amended in 2011 to give effect to the parliament decision to abandon the use of nuclear energy. ${ }^{70}$

The consequence of the amendment of the law is that the Brunsbüttel and Krümmel nuclear power plants, for which Vattenfall has operating responsibility and owns $66.7 \%$ and $50 \%$, respectively, may not be restarted. Vattenfall claim the breach of rights accruing from the EU Energy Charter Treaty. ${ }^{71}$ Vattenfall is reportedly requesting $€ 3.7$ billion in compensation. ${ }^{72}$ The case is still pending and the last activity on record shows that the Tribunal issued the first procedural Order on procedural matters on $17^{\text {th }}$ July $2013^{73}$

http://www.italaw.com/cases/851 accessed on 6/08/2013.

${ }^{60}$ As above para 6 of the Notice of Claim under the Australia - Hong Kong Agreement dated 27/06/2011 available at http://www.italaw.com/sites/default/files/case-documents/ita0664.pdf accessed on 6/08/2013; see also the Notice of Arbitration para 1.2 available at $h$ ttp://www.italaw.com/sites/default/files/case-documents/ita0665.pdf accessed on 06/08/2013.

${ }^{61}$ As above.

${ }^{62}$ As above para $1.5-1.7$.

${ }^{63}$ As above para 1.5

${ }^{64}$ As above para 1.7 .

65 The last Procedural Order regarding Amendment of the Timetable was issued on $31^{\text {st }}$ December 2013 and is available at http://www.italaw.com/sites/default/files/case-documents/italaw1309.pdf accessed on 06/08/2013.

66 See the WHO Framework Convention on Tobacco Control, (2003) 42 ILM 3, 518-539, available at http://www.fctc.org/about-fca/tobacco-control-treaty accessed on 20/06/2014. The Treaty came in force on 27/02/2005

${ }^{67}$ Vattenfall $A B$ and others $v$ Federal Republic of Germany ICSID Case No ARB/12/12

68 See the case procedural details available at

https://icsid.worldbank.org/ICSID/FrontServlet?requestType $=$ CasesRH\&reqFrom $=$ ListCases \& caseId $=C 2220 \&$ actionVal=viewCase accessed on 07/08/2013.

${ }^{69}$ The Fukushima Nuclear reactors failure caused 160,000 people to flee their homes in japan in 2011. For more on this see Green Peace International available at http://www.greenpeace.org/international/en/campaigns/nuclear/safety/accidents/Fukushima-nuclear-disaster/ accessed on 03/07/2014.

${ }^{70} \mathrm{~N}$ Bernasconi - Osterwarder \& RT Hoffman The German Nuclear Phase-Out Put to the Test in International Investment Arbitration?, IISD Briefing Note, June 2012 available at $h t t p: / / w w w . i i s d . o r g / p d f / 2012 / g e r m a n \_n u c l e a r \_p h a s e \_o u t . p d f$ accessed on 07/08/2013.

${ }^{71}$ The European Energy Charter available at $h t t p: / / w w w . e n c h a r t e r . o r g / f i l e a d m i n / u s e r \_u p l o a d / d o c u m e n t / E N . p d f$

${ }^{72} \mathrm{~N}$ Bernasconi - Osterwarder \& Hoffman RT, note 70 above.

73 See $\quad$ the $\quad$ Pase Details available at 
Again, this case arises from the state's exercising regulatory powers on public health matters. One would expect that the respective tribunal would consider the necessity of the measure taken by the government and balance it with foreign investor interests. It is worrying however as investor - state Tribunals are not consistently doing that. For example the Tribunal in Santa Elena v Costa Rica, ${ }^{74}$ held that:

'Expropriatory environmental measures-no matter how laudable and how beneficial to society as a whole-are in this respect, similar to any other expropriatory measure that a state may take in order to implement its policies... where property is expropriated, even for environmental purposes, whether domestic or international, the state's obligation to pay compensation remains'.

With the Santa Elena trend, it will not be surprising if the Philip Morris tribunal and the Vattenfall Tribunal find the respondent states liable to the foreign investor despite the magnitude of the measure on public health.

\section{The Parallel Nature of State's Obligation to Foreign Investors \& Public Health}

As evidenced in the discussion above, states have multiple international and national obligations. States has the duty among others to protect the foreign investors' interests in its territory. But also states have the primary duty to protect health of its citizens also from international and national instruments. The problem comes when the implementation of the two obligations conflict each other and demand the government to violate one in order to implement the other. Which obligation should prevail over the other is a question which has been given a critical consideration under this part of the discussion. It is submitted herein below that states have the duty to fulfil both obligations in parallel. The basis for this argument is the Vienna Convention on the Law of Treaties (VLCT) and relevant cases decided by the Court of Justice of the European Union (CJEU) and the WTO.

\subsection{The Vienna Convention on Law of Treaties}

The Vienna Convention on the Law of Treaties is the guiding instrument with regards to treaties interpretation. ${ }^{76}$ The Preamble requires the adjudicators to perform their function of settling disputes 'in conformity with the principles of justice and international law'. The principles of international law on treaty interpretation are codified through Article 31 and 32 of the VLCT. Article 31 provides that 'a treaty shall be interpreted in good faith in accordance with the ordinary meaning to be given to the terms of the treaty in their context and in the light of its object and purpose' ${ }^{77}$

It is submitted here that by requiring that a treaty should be interpreted in the light of its object and purpose the VLCT intended to limit the scope of the respective treaty in question. This means that any adjudicators on a particular treaty are not supposed to give a wider scope to a treaty which would otherwise go beyond its scope. In other words, Article 31(1) requires interpreters to take the whole treaty into account when adopting the necessary measures to prevent over extension of the rights provided therein. The purpose of a BIT, for example, is to guarantee foreign investors with specific rights and not to override other host state obligations created through other treaties. It follows therefore that any interpretation by arbitrators which gives investors' interests' priority over other host state obligation is not living up to the object and purpose for which the BIT was created for.

In addition, Article 31(3) (c) requires that in the course of interpreting any treaty relevant rules of international law applicable in the relations between the parties need to be taken into consideration. ${ }^{78}$ One of such rules of international law is the right of sovereign state to exercise regulatory powers including, among other things, enactment and enforcement of regulations on a range of issues, including public health. Therefore a proper interpretation of Article 31(3) (c) in as far as balancing treaty obligations is concerned, would be that tribunals in the course of interpreting BITs and IIAs need to do so with other social values in mind; human rights, public health and environmental considerations. It follows further that tribunals need not blindly interpret BITs as if they exist in isolation but should interpret them in a manner that they would not undermine other host state's international obligations. ${ }^{79}$

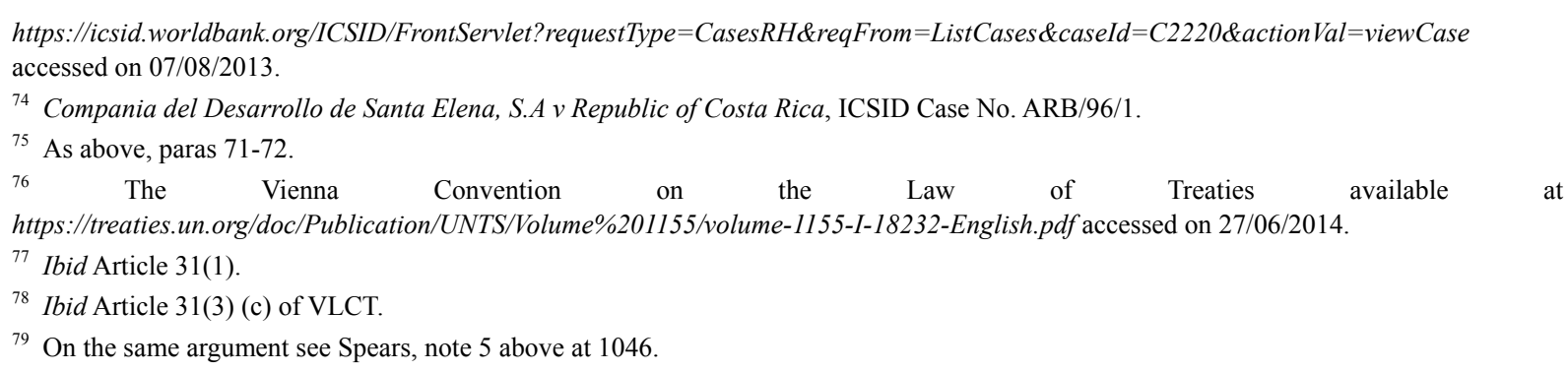




\subsection{Jurisprudence on Private Property vs Public Interest}

Courts have also been able to put to light the scope of property protection versus public interests including public health. The European Court of Justice in Booker Aquaculture and Hydro Seafood ruled that the protection of public health is a general interest which can even justify substantial adverse consequences for freedom of trade and property rights. ${ }^{80}$

In another case Swedish Match cases, the ECJ recognized that the prohibition of the marketing of tobacco for oral use restricted free trade, but stressed that such a regulation was intended to protect a high level of health, which is an objective of general interest. ${ }^{81}$

The WTO as well has recognised the need to balance the trade interests Vis a Vis other social regulatory powers of the state parties. In US V Gasoline ${ }^{82}$ case the US measure to regulate the composition and emission effects of gasoline in order to reduce air pollution was held valid despite the fact that it interfered with trade. Again, in European Communities - Measures Affecting Asbestos and Asbestos-Containing Products, ${ }^{83}$ the court decided to uphold French public health objective over Canada trade objectives. Also in Brazil - Re-treaded Tyres ${ }^{84}$ the Appellate Body affirmed the relevancy of non - trade policies by holding that the import ban on re-treaded tyres was apt to produce a material contribution to the achievement of its objective i.e. the reduction in waste tyre volumes. ${ }^{85}$

\section{Way Forward}

Despite the clear guidance from the VLCT, Tribunals have failed to balance the host state health obligations Vis a Vis foreign investors interests. As seen in Biwater Gauff (Tanzania) Ltd $v$ United Republic of Tanzania ${ }^{86}$ and in Santa Elena $v$ Costa Rica, ${ }^{87}$ discussed earlier, tribunal focuses more on protecting foreign investors interests without giving regard to the necessity of the state measure.

As seen in the discussion above, Tanzania BITs, with exception of Tanzania - Canada BIT are all silent on public health matters. Which means, as earlier pointed out, tribunals constituted to deal with a dispute between a foreign investor and Tanzania as a host state are not specifically obliged by the state parties to take into consideration government regulatory powers on public health issues. It follows therefore that, Tanzania runs a risk of being found guilty for enacting legislations which are meant to protect public health. As earlier evidenced, foreign investors in Philip Morris Asia Ltd v The Commonwealth of Australia ${ }^{88}$ and Vattenfall AB and others v. Federal Republic of Germany ${ }^{89}$ are up in arms suing Australia and Federal Republic of Germany respectively for exercising regulatory powers of legislating on public health.

Therefore Tanzania need to get her house in order before the Australian and Germany experience befalls it. There are a number of ways of addressing or curbing the situation. The most fulfilling and trending ones includes: renegotiation of the BIT so as to include treaty interpretative statements or formulate a model BIT which balances foreign investors interests with the host state power to regulate on public health and non - investment issues.

\subsection{Renegotiate to Include Interpretative Statements}

The fact that a BIT is a creature of the respective state parties' consent, it is just logical for the state parties to be given the mandate to provide the guidelines on how the BIT provisions should be interpreted. ${ }^{90}$ The state parties should not leave the door wide open for tribunal to go around searching the intention of the state parties. As

${ }^{80}$ Opinion of 20 September 2001 of AG Mischo in Joined Cases C-20/00 and C-64/00 Booker Aquaculture and Hydro Seafood [2003] ECR 7411.

${ }^{81}$ Case C-210/03 Swedish Match [2003] ECR I-11893.

${ }^{82}$ US V Gasoline WT/DS2/AB/R (29 April 1996).

${ }^{83}$ European Communities-Measures Affecting Asbestos and Asbestos-Containing Products WT/DS135/AB/R (12 March 2001).

${ }^{84}$ Brazil - Re-treaded Tyres WT/DS332/AB/R (12 June 2007)

${ }^{85}$ As above.

${ }^{86}$ Biwater Gauff, note 50 above.

${ }^{87}$ Santa Elena, note 74 above.

${ }^{88}$ Philip Morris, note 59 above.

${ }^{89}$ Vattenfall, note 67 above.

90 see UNCTAD IIIA Issues Note, 'Interpretation of IIAs: What State can Do' December 2011, available at http://unctad.org/en/docs/webdiaeia2011d10_en.pdf accessed on 03/03/2014; see also See UNCTAD IIA Issues Note 'Reform of Investor State Dispute Settlement: In Search of a Roadmap' $26^{\text {th }}$ June 2013 available at http://unctad.org/en/PublicationsLibrary/webdiaepcb2013d4_en.pdf. accessed on 03/03/2014. 
discussed before, the majority of Tanzanian BITs do not address Tanzania power to regulate on non- investment hence leaving the country vulnerable on this area. Government regulatory measures on public health could lend the country in the hands of the International Centre for Settlement of Investment Disputes tribunal or UNCITRAL tribunal and punitive damages may befall thereafter. The fact that most of the FDI entering the country are on extraction industry which, at times, affect the health of the community surrounding these extracting firms, calls for Tanzania to seek for interpretative statement before it is too late. For example, in May 2009, toxic sludge from the mine seeped into the Thigithe River in Tarime Mara. Reports from the surrounding villages alleged that the toxic material led to the deaths of about 20 people and to fish, crops and animals dying from the contaminated water. The following year, controversy raged in Tanzania's parliament as activists, villagers and human rights organizations tried to have the mine shut down. ${ }^{91}$ It should be understood here that had the parliament decided to instruct the government to close the mine that would have warranted institution of a claim with ICSID by the foreign investor alleging expropriation and failure to accord fair and equitable treatment. The existing BITs would have invoked in favour of the foreign investor as they only provide for foreign investors rights and are silent on state right to regulate on public health.

It is submitted here that with such a lacuna in Tanzania BITs, it is ripe time to seek renegotiation of the BITs so as to allow state parties to have the power to provide interpretative statement that BITs rights are not meant to override other state obligations. The interpretative statement could go as far as stipulating the investors' duty to observe environmental, health, cultural regulations.

Other jurisdictions have managed to incorporate the interpretative statements in their Model BITs. The Canadian Model BIT under Article 40 (2) establishes a Commission constituted by Cabinet - level representatives from the BIT member States. ${ }^{92}$ The Article further provides that the interpretative note shall be binding on the Tribunal and any award shall be required to conform to the interpretative statement. ${ }^{93}$ In addition, Article 28 of Canada and the States of the European Free Trade Association which constitute Iceland, Liechtenstein, Norway and Switzerland provide for the establishment of the interpretative commission. ${ }^{94}$ The same is provided for in the Canadian agreements with Colombia ${ }^{95}$, Peru, ${ }^{96}$ Chile, ${ }^{97}$ Costa Rica, ${ }^{98}$ Jordan $^{99}$ and Israel. ${ }^{100}$

In the same spirit, the US Model BIT 2004, while does not establish a Commission as its counterpart Canada, it takes recognition of the member state parties' joint interpretation on any provision of the BIT. ${ }^{101}$ The Model BIT considers such interpretation binding on a Tribunal and the award rendered thereby has to be in line with the joint interpretative statement. ${ }^{102}$ the U.S.-Australia Free Trade Agreement, ${ }^{103}$ the U.S.-Chile Free Trade Agreement, ${ }^{104}$ and the recent agreements with Colombia, Korea, Morocco, Oman, Panama, Peru, Rwanda and Singapore all

91 See Tanzanian villagers sue London-based African Barrick Gold for deaths and injuries available at http://protestbarrick.net/article.php?id=928 accessed on 23/06/2014.

92 Canadian Model BIT, 2004 available at http://italaw.com/documents/Canadian2004-FIPA-model-en.pdf accessed on 25/02/2014.

93 As above, Article 40(2).

94 Free Trade Agreement between Canada and the States of the European Free Trade Association available at http://www.efta.int/media/documents/legal-texts/free-trade-relations/canada/EFTA-Canada\%20Free\%20Trade\%20Agreement\%20EN.pdf accessed on $26 / 02 / 2014$.

95 See Article 832 of the Canada-Colombia Free Trade Agreement of 21/11/2008 available at http://www.international.gc.ca accessed on $26 / 02 / 2014$

96 See Article 50 of the Agreement Between Canada and the Republic of Peru for the

Promotion and Protection of Investments available at http://www.international.gc.ca accessed on 26/02/2014.

97 See Art. N-01 of the Canada-Chile Free Trade Agreement of 05/07/1997 available at http://www.international.gc.ca accessed on $26 / 02 / 2014$

98 See Art. XIII.1, of the Canada-Costa Rica Free Trade Agreement of 01/11/2002 available at http://www.international.gc.ca accessed on 26/02/2014.

99 See Article 40 of the Agreement Between Canada and the Hashemite Kingdom of Jordan for

the Promotion and Protection of Investments of 28/06/2009 available at http://www.international.gc.ca accessed on 26/02/2014.

100 See Article 8(2) of the Canada-Israel Free Trade Agreement of 01/01/1997 available at http://www.international.gc.ca accessed on 26/02/2014.

101 See Article 30(3) of the Us Model BIT, 2004 available at http://www.state.gov/documents/organization/117601.pdf accessed on 25/02/2014.

102 Ibid Article 30(3) of the Us Model BIT, 2004

103 See the United States-Australia Free Trade Agreement of 01/01/2005 available at http://www.ustr.gov/trade-agreements/free-trade-agreements/australian-fta/final-text accessed on 26/02/2014.

104 See the United States-Chile Free Trade Agreement of 01/01/2004 available at http://www.ustr.gov/trade-agreements/free-trade-agreements/chile-fta accessed on 26/02/2014. 
provides for the establishment of an interpretative statement by member states representatives. ${ }^{105}$

It is submitted here that Tanzania has the right to ask partner member states to each BIT to renegotiate the BIT so as to include a provision which provides for the establishment of interpretative statements commission. Renegotiating a BIT to achieve the intended goal is within the powers of state parties. ${ }^{106}$ The Permanent Court of International Justice once held that the right of giving an authoritative interpretation of a legal rule belongs solely to the person or body who has power to modify or suppress it. ${ }^{107}$

\subsection{Adopt the Canada - Tanzania BIT as a Model BIT}

As discussed earlier, the Canada - Tanzania BIT which was signed last year has addressed host state non investment regulatory powers. This is a right direction to go as foreign investment is not the end itself but one of the means to the end. Canada - Tanzania BIT recognises that while investment protection and promotion remains the principal objective of the IIA, the objective has to be achieved in a manner consistent with the protection of health, safety, and the environment. The BIT in other words signifies that the parties do not intend to relinquish their right to regulate or their flexibility to address issues relating to the public interest.

Therefore as there is no Model BIT so far which Tanzania is following, it is suggested here that the CanadaTanzania BIT should be adopted by the government as its model BIT to which all future BITs will be benchmarked upon. This will help the country from falling into the trap of entering into a BIT resembling the existing 16 BITs which do not balance the host state power to regulate Vis a Vis foreign investors rights.

\section{Conclusion}

In conclusion, it can be said here that investor - state tribunals as institutions empowered to interpret treaties need to adhere to the VLCT article 31(3) (c) which demand them to do their job by taking into account other international law rules. State's power to regulate is among the international law rules. Hence tribunals need to take cognisance of the state power to regulate and interpret BIT in a manner that will avoid as much as possible conflict with the regulatory powers of the host state on other matters, including public health. Meanwhile, it is further submitted that it is right time for Tanzania to consider renegotiating its BITs which hinders its capacity to regulate on public health. As a sovereign state it has an international obligation to ensure public health is maintained at highest standard possible. This obligation is provided as well in the constitution and other local legislations. Renegotiating the treaties will put the country at a better place of addressing public health issues and other non-investment obligation. alongside that, for future BITs Tanzania should consider making Tanzania Canada BIT as its Model BIT as it is more balanced and give the state parties more power to regulate on non-investment issues.

\footnotetext{
105 See these FTAs at http://www.ustr.gov/trade-agreements/free-trade-agreements accessed on 26/02/2014.

106 R Anthea 'Power and Persuasion in Investment Treaty Interpretation: The Dual Role of States' (2010) 104 American Journal of International Law at 225.

107 See Permanent Court of International Justice, Jaworzina, Advisory Opinion, 1923, P.C.I.J., Series B, No. 8, p. 37.
} 